\title{
Intestinal Maturation: Effect of Luminal Osmolality on Net Mineral Secretion
}

\author{
FAYEZ K. GHISHAN, ${ }^{(18)}$ PAUL H. PARKER, AND GERARD L. HELINEK
}

Vanderbilt University Hospital, Department of Pediatric Gastroenterology, Nashville, Tennessee, USA

\begin{abstract}
Summary
We investigated with an in vivo single-pass perfusion technique net secretion of calcium, magnesium, and zinc from proximal and distal small intestinal segments and from the cecum plus colon segments of suckling, weanling, and adolescent rats during perfusion with either isotonic $(300 \mathrm{mOsm} / \mathrm{kg})$ or hypertonic $(500$ $\mathrm{mOsm} / \mathrm{kg}$ ) mineral-free solutions. There was net secretion of calcium, magnesium, and zinc in all segments perfused at all age periods.

During isotonic perfusion, rates of net secretion of calcium and zinc were severalfold greater in the proximal and distal segments of the suckling rats compared with the corresponding segments of the adolescent rats. Net magnesium secretion was similar in the suckling and adolescent rats. Net secretion rates for the weanling rats tended to be intermediate. During hypertonic perfusion, net secretion rates for calcium, magnesium, and zinc were severalfold greater from all segments of the suckling rats compared with the corresponding segments of the adolescent rats. During either isotonic or hypertonic perfusions, rates of net secretion of calcium and magnesium in general were greater from the proximal and distal segments than from the cecum plus colon in the suckling and weanling rats. In contrast, for the adolescent rats, net secretions from all segments in general were similar. For zinc, rates of net secretion were somewhat greater in the cecum plus colon of rats in all age groups.
\end{abstract}

Our findings suggest a greater permeability of the intestinal epithelium, not only to water and electrolytes but also to certain minerals (calcium and magnesium) and trace elements $(\mathrm{Zn})$ in suckling rats compared with adolescent rats. The implication is that during periods of osmotic diarrhea, infant animals appear to be at risk for losing excessive amounts of minerals and trace elements. These findings may have clinical relevance to human infants suffering from recurrent diarrheal diseases.

\section{Speculation}

The changes in the rate of net secretion of minerals in the small and large intestine of the rats during maturation could be the result of alterations in the biochemical composition of the intestinal mucosal membrane that occur with maturation. These alterations in the biochemical composition appear to decrease the permeability of the mucosal membranes along the length of the intestinal tract.

It is generally recognized that most organ systems of various mammalian species exhibit characteristic developmental patterns (5). The gastrointestinal system of the infant rat demonstrates this phenomenon by evidence suggesting increased permeability when compared with the older rat $(4,14,15)$. When the small intestine of the infant rat was perfused with calcium-containing solutions, a linear relationship existed between luminal calcium concentration, the lumen-to-mucosa flux, and net calcium transport. This suggested that transport of calcium was primarily by a passive diffusive process. In contrast, in the adolescent rat, the relationship was curvilinear which suggested that transport of calcium was primarily by an active saturable mechanism (4). When the osmolality of a diet fed to infant rats was increased, the animals experienced significant hemoconcentration and increased serum osmolality which suggested a loss of fluid to the intestinal lumen (7). Similarly, when subjected to experimental osmotic diarrhea, the small intestine of the infant rat lost greater quantities of water, sodium, chloride, and calcium than did the adolescent rat $(3,15)$.

Currently, the studies investigating permeability differences in the rat intestine have focused on water and sodium fluxes while using isotonic and hypertonic perfusion solutions $(6,15)$. There is information concerning calcium losses in the small intestine during hypertonic perfusions in infant and adolescent rats; however, the effects on the cecum and colon were not investigated. To our knowledge, there is no information concerning potential small and large intestinal losses of magnesium and zinc or potential colonic losses of calcium in rats of different ages who are subjected to experimental osmotic diarrhea. Therefore, using an in vivo singlepass perfusion technique, we studied net secretion of calcium, magnesium, and zinc in proximal and distal small intestinal segments and in the combined cecum plus colon segment of rats. The age groups included the suckling (14- to 15-day), the weanling (21- to 22-day) and the adolescent (42- to 43-day) periods. Each group was studied with both isotonic $(300 \mathrm{mOsm} / \mathrm{kg})$ and hypertonic $(500 \mathrm{mOsm} / \mathrm{kg}$ ) perfusion solutions.

\section{MATERIALS AND METHODS}

Transport of water and minerals (calcium, magnesium, and zinc) in segments of the proximal and distal small intestine and in the cecum plus colon was assessed in suckling, weanling, and adolescent albino rats. Litters of the suckling and weanling animals were obtained from pregnant rats purchased from Harland Industries, Indianapolis, IN. On the second day after delivery, the pups were randomized among the dams. The litter size was restricted to 8 to 10 pups. Adolescent rats weighing between 140 and $150 \mathrm{~g}$ were obtained directly from Harland Industries.

The experimental procedures using an in vivo single-pass perfusion technique were similar to those previously described $(4,14$, 15). At the time of the study, unfasted rats were anesthetized with a mixture of ethylurea (K \& K Laboratories, Inc., Plainview, NY) and sodium pentobarbital with a $6: 1$ ratio. The abdominal cavity was opened, and the intestinal tract was divided into three segments. The proximal segment extended from a point just distal to the pylorus to a point 5 to $10 \mathrm{~cm}$ distal to the ligament of Treitz. The distal segment extended for 15 to $20 \mathrm{~cm}$ of the ileum to a point just proximal to the ileocecal valve. The third segment included the entire cecum and colon. Inlet and outlet cannulae were inserted into each segment. The segments were flushed first with 10 to $20 \mathrm{ml}$ of warm normal saline and second with 25 to 50 $\mathrm{ml}$ of air. The segments were tucked within the abdominal cavity; and as the rats lay on heating pads, the peritoneal temperature was monitored to maintain $36-37^{\circ} \mathrm{C}$.

The segments were perfused in situ at a rate of $0.4 \mathrm{ml} / \mathrm{min}$. The perfusion solutions contained per liter: 154 mmoles sodium chloride, $30 \mathrm{mg}$ phenol red, and mannitol (Fisher Scientific Co., Pittsburg, PA) in quantities sufficient to achieve osmolalities of 
300 and $500 \mathrm{mOsm} / \mathrm{kg}$ which were determined by a freezing point osmometer (model 3W; Advanced Instruments, Needham Heights, MA). The perfusion solutions were essentially free of calcium, magnesium, and zinc.

To investigate the effects of isotonic and hypertonic solutions on net secretion of calcium, magnesium, and zinc from various intestinal segments, five to eleven rats were studied at each age period. Each rat underwent $90 \mathrm{~min}$ of perfusion. The initial 30 min allowed for equilibration, and the perfusate was discarded. During the remaining time, the perfusate was collected from each segment in three 20 -min periods. In the initial perfusion solutions and in each collected perfusate, the concentrations of calcium, magnesium, zinc and phenol red were determined. At the end of the experiment, the perfused segments were stripped from the mesentery, and their lengths were measured. The wet weight of the segments were determined after gentle expression of the luminal contents with the forefinger. The segments were dried in a vacuum oven at $90-95^{\circ} \mathrm{C}$ for $24 \mathrm{hr}$, and the dry weights were determined. The concentrations of calcium, magnesium, and zinc were measured in the perfusates by atomic abosorption spectrometry (model 603; Perkin-Elmer Corp, Norwalk, CO). Phenol red concentrations were determined by a spectrophotometer (Model 25; Beckman Instruments, Inc., Fullerton, CA) with a previously described method (9).

Net water transport was determined from changes in phenol red concentrations as follows:

$$
\text { Net water transport }(\mathrm{ml} / 20 \mathrm{~min})=\mathrm{V}\left(1-\mathrm{PR}_{\mathrm{i}} / \mathrm{PR}_{\mathrm{f}}\right)
$$

where $\mathrm{V}$ represents the volume of the perfusate collected during each 20-min period, and PR represents the concentration of phenol red in $\mu \mathrm{g}$, in the perfusion fluids. The subscripts $\mathrm{i}$ and $\mathrm{f}$ designate the initial and final concentrations in the perfusion solutions and the perfusates, respectively.

Net secretion of minerals was calculated using the following formula:

$$
\text { Net transport, } \mu \text { moles } / 20 \min =\mathrm{V}\left(\mathrm{C}_{\mathrm{i}}-\mathrm{C}_{\mathrm{f}} \mathrm{PR}_{\mathrm{i}} / \mathrm{PR}_{\mathrm{f}}\right)
$$

where $\mathrm{C}$ represents concentration $(\mu \mathrm{moles} / \mathrm{ml})$ of mineral in perfusion fluids.

During the 60 -min collection period, steady-state conditions were achieved because net transport of water and minerals during each 20-min collection period did not vary from each other by more than $20 \%$. The amounts of water and minerals transported during the three periods were added to obtain the amount transported in $1 \mathrm{hr}$. To compare transport rates of water and minerals in segments from rats of different age groups, the quantities transported were normalized for the marked differences in the weights of the perfused segments. Transport rates were expressed per unit weight to indicate "secretory specific activity" of the segment and per unit length to indicate "total secretory capacity" of the segment. To evaluate the effect of perfusion on the epithelial cells of the intestine, microscopic examination of the sediment of the perfusion was carried out at the end of the study period.

Statistical analysis was performed as follows. The unpaired Student $t$ test was used to compare mean values between corresponding segments in different age groups for either the isotonic or the hypertonic series as well as to compare mean values between corresponding segments within each age group for these isotonic and hypertonic series. A value of $P<0.05$ was accepted as indicating a statistically significant difference between corresponding mean values (1)

\section{RESULTS}

Body weights and measurements on the perfused intestinal segments are presented in Table 1 . In the adolescent rats, the wet weights per $\mathrm{cm}$ of perfused segment were severalfold greater than in corresponding segments of the suckling rats. During perfusion with a hypertonic solution, water content of all segments of the suckling and weanling rats decreased significantly $(P<0.05-$ $0.01)$ when compared with perfusion with an isotonic solution.
However, in a similar comparison of the adolescent rats, only the cecum plus colon segments demonstrated a significant decrease in water content $(P<0.02)$.

Rates of net secretion of calcium, magnesium, and zinc which are expressed on the basis of per unit wet and dry weight and per unit length of the perfused intestinal segments are presented in Table 2. Rates of net transport of water per unit net weight is also presented in Table 2.

\section{NET WATER TRANSPORT}

When different age groups were considered, the net water secretion was significantly greater $(P<0.05)$ in the suckling rats compared with the adolescent rats in both the isotonic and hypertonic perfusion groups. Within the individual age groups, suckling and weanling rats demonstrated significantly greater $(P<0.05)$ net water secretion in all segments except the distal segments of the suckling rats in response to hypertonic solutions compared with isotonic solutions. However, in the adolescent rats, net water secretion increased significantly $(P<0.01)$ only in the proximal segments.

\section{NET CALCIUM SECRETION}

When different age groups were considered, during isotonic perfusion, the net calcium secretion based on both wet and dry weights was significantly greater $(P<0.02)$ in the proximal and distal segments of the suckling rats compared with the adolescent rats. Similarly, during hypertonic perfusion, net calcium secretion was significantly greater $(P<0.05)$ in the corresponding segments of the suckling rats compared with the adolescent rats. In the cecum plus colon segments of these two age groups, during hypertonic perfusion, these segments in suckling rats demonstrated significantly greater $(P<0.05)$ net calcium secretion compared with adolescent rats. Rates of net calcium secretion in the weanling rats tended to be intermediate between the corresponding values for the suckling and adolescent rats. Within age groups, hypertonic perfusion of the segments resulted in significant increases $(P<$ 0.05 ) in net calcium secretion based on wet weights in the proximal segments and based on wet and dry weights in the cecum plus colon segments of the suckling rats. In the adolescent rats, a significant difference based on wet and dry weights occurred only in the proximal segments. Somewhat unexpectedly, there were no differences in any segments of the weanling rats.

\section{NET MAGNESIUM SECRETION}

When the different age groups were considered, during isotonic perfusion, net magnesium secretion based on wet and dry weights was similar in all segments of the suckling, weanling, and adolescent rats. However, during hypertonic perfusion, net magnesium secretion based on wet and dry weights increased significantly $(P$ $<0.05$ ) in the proximal and cecum plus colon segments of the suckling rats compared with the adolescent rats. Within age groups, when hypertonic perfusion was compared with isotonic perfusion, net magnesium secretion demonstrated a significant difference based on all parameters in the proximal segments and a significant difference based on wet weights in the cecum plus colon of the suckling rats. There were no significant differences in the rates of net magnesium secretion within either the weanling or adolescent age groups.

\section{NET ZINC SECRETION}

When the different age groups were considered during both isotonic and hypertonic perfusions, net zinc secretion based on wet and dry weights was significantly greater $(P<0.02)$ in all segments of the suckling rats compared with the adolescent rats. Net zinc secretion for both the isotonic and hypertonic perfusions in the weanling group was significantly greater $(P<0.02)$ than both the suckling and the adolescent groups. Within age groups, when hypertonic perfusion was compared with isotonic perfusion, net zinc secretion based on wet weights was significantly greater 
Table 1 Age, body weight, and measurements of the intestinal segments in the rats studied

\begin{tabular}{|c|c|c|c|c|c|c|c|c|c|c|c|c|c|c|c|c|c|}
\hline & \multirow[b]{2}{*}{$\begin{array}{l}\text { Perfusion } \\
\text { solution os- } \\
\text { molality } \\
(\mathrm{mOsm} / \mathrm{kg})\end{array}$} & \multirow[b]{2}{*}{ No. } & \multicolumn{5}{|c|}{ Proximal segment } & \multicolumn{5}{|c|}{ Distal segment } & \multicolumn{5}{|c|}{ Cecum and colon segment } \\
\hline & & & $\begin{array}{l}\text { Length } \\
(\mathrm{cm})\end{array}$ & $\begin{array}{c}\text { Total wet wt } \\
\text { (g) }\end{array}$ & $\mathrm{mg} / \mathrm{cm}$ & $\begin{array}{c}\text { Total dry } \\
\text { wt (mg) }\end{array}$ & $\begin{array}{c}\text { Water } \\
\text { content } \\
(\mathrm{mg} / 100 \\
\mathrm{mg})\end{array}$ & $\begin{array}{c}\text { Length } \\
(\mathrm{cm})\end{array}$ & $\begin{array}{c}\text { Total wet wt } \\
\text { (g) }\end{array}$ & $\mathrm{mg} / \mathrm{cm}$ & $\begin{array}{l}\text { Total dry } \\
\text { wt (mg) }\end{array}$ & $\begin{array}{c}\text { Water } \\
\text { content } \\
(\mathrm{mg} / 100 \\
\mathrm{mg})\end{array}$ & $\begin{array}{l}\text { Length } \\
(\mathrm{cm})\end{array}$ & $\begin{array}{c}\text { Total wet } \\
\text { wt }(\mathrm{g})\end{array}$ & $\mathrm{mg} / \mathrm{cm}$ & $\begin{array}{l}\text { Total dry } \\
\text { wt (mg) }\end{array}$ & $\begin{array}{c}\text { Water } \\
\text { content } \\
(\mathrm{mg} / 100 \\
\mathrm{mg})\end{array}$ \\
\hline \multicolumn{18}{|l|}{$\begin{array}{l}\text { Suckling (14-15 } \\
\text { days) }\end{array}$} \\
\hline $\begin{array}{l}\text { Body wt }(26.2 \\
\pm 1.06 \mathrm{~g})\end{array}$ & 300 & 6 & $15 \pm 3^{1}$ & $0.26 \pm 0.04$ & $18 \pm 2$ & $55 \pm 7$ & $80 \pm 1$ & $17 \pm 2$ & $0.25 \pm 0.04$ & $15 \pm 1$ & $49 \pm 6$ & $81 \pm 2$ & $5 \pm 2$ & $0.10 \pm 0.01$ & $22 \pm 2$ & $18 \pm 2$ & $82 \pm 1$ \\
\hline $\begin{array}{l}\text { Body wt ( } 27.7 \\
\pm 9 \mathrm{~g})\end{array}$ & 500 & 11 & $17 \pm 1$ & $0.20 \pm 0.01$ & $13 \pm 1$ & $61 \pm 7$ & $74 \pm 2^{2}$ & $18 \pm 2$ & $0.22 \pm 0.03$ & $13 \pm 1$ & $54 \pm 5$ & $76 \pm 1^{2}$ & $4 \pm 0.4$ & $0.07 \pm 0.01$ & $17 \pm 2$ & $16 \pm 2$ & $74 \pm 1^{2}$ \\
\hline \multicolumn{18}{|l|}{$\begin{array}{l}\text { Weanling (21-22 } \\
\text { days) }\end{array}$} \\
\hline $\begin{array}{l}\text { Body wt }(42.0 \\
\pm 1.7 \mathrm{~g})\end{array}$ & 300 & 5 & $19 \pm 2$ & $0.55 \pm 0.01$ & $34 \pm 3$ & $109 \pm 6$ & $81 \pm 1$ & $22 \pm 2$ & $0.53 \pm 0.11$ & $26 \pm 1.2$ & $111 \pm 20$ & $79 \pm 1$ & $7 \pm 0.1$ & $0.35 \pm 0.04$ & $53 \pm 6$ & $64 \pm 4$ & $80 \pm 1$ \\
\hline $\begin{array}{l}\text { Body wt }(41.9 \\
\pm 1.5 \mathrm{~g})\end{array}$ & 500 & 7 & $19 \pm 1$ & $0.40 \pm 0.05$ & $23 \pm 2$ & $104 \pm 9$ & $74 \pm 1^{2}$ & $22 \pm 2$ & $0.40 \pm 0.06$ & $18 \pm 2$ & $101 \pm 10$ & $73 \pm 1^{2}$ & $7 \pm 0.3$ & $0.27 \pm 0.03$ & $39 \pm 4$ & $58 \pm 7$ & $75 \pm 1^{2}$ \\
\hline \multicolumn{18}{|l|}{$\begin{array}{l}\text { Adolescent (42-43 } \\
\text { days) }\end{array}$} \\
\hline $\begin{array}{l}\text { Body wt }(144 \pm \\
\quad 3 \mathrm{~g})\end{array}$ & 300 & 5 & $35 \pm 3$ & $2.3 \pm 0.22$ & $70 \pm 4$ & $458 \pm 40$ & $80 \pm 1$ & $35 \pm 2$ & $2.0 \pm 0.1$ & $60 \pm 2$ & $395 \pm 40$ & $80 \pm 1$ & $13 \pm 3$ & $1.9 \pm 0.1$ & $142 \pm 6$ & $318 \pm 19$ & $81 \pm 2$ \\
\hline $\begin{array}{l}\text { Body wt (146 } \\
3 \mathrm{~g})\end{array}$ & 500 & 5 & $28 \pm 7$ & $2.8 \pm 0.7$ & $66 \pm 4$ & $474 \pm 60$ & $80 \pm 0.4$ & $31 \pm 2$ & $1.8 \pm 0.2$ & $56 \pm 7$ & $361 \pm 50$ & $79 \pm 1$ & $14 \pm 2$ & $1.6 \pm 0.1$ & $112 \pm 5$ & $369 \pm 22$ & $77 \pm 0.6^{2}$ \\
\hline
\end{tabular}

'Mean \pm S.E.

${ }^{2}$ Mean values are significantly lower than corresponding values during perfusion with isotonic solution. 
Table 2. Net calcium, magnesium, zinc, and water transport during perfusion of the isotonic and hypertonic solutions in the intestinal segments studied

\begin{tabular}{|c|c|c|c|c|c|c|c|c|c|c|}
\hline \multirow[b]{3}{*}{ Perfusion } & \multicolumn{10}{|c|}{ Proximal } \\
\hline & \multicolumn{3}{|c|}{ Calcium } & \multicolumn{3}{|c|}{ Magnesium } & \multicolumn{4}{|c|}{ Zinc } \\
\hline & $\begin{array}{c}\mu \text { moles/ } \\
\mathrm{hr} / 0.1 \mathrm{~g} \\
\text { total wet } \\
\mathrm{wt}\end{array}$ & $\begin{array}{c}\mu \text { moles/ } \\
0.1 \mathrm{~g} \text { total } \\
\text { dry wt }\end{array}$ & $\begin{array}{l}\mathrm{m} \mu \text { moles/ } \\
\mathrm{cm} \text { length }\end{array}$ & $\begin{array}{c}\mu \text { moles/ } \\
\mathrm{hr} / 0.1 \mathrm{~g} \\
\text { total wet } \\
\mathrm{wt}\end{array}$ & $\begin{array}{c}\mu \text { moles/ } \\
0.1 \text { g to- } \\
\text { tal dry } \\
\text { wt }\end{array}$ & $\begin{array}{l}\mathrm{m} \mu \text { moles/ } \\
\mathrm{cm} \text { length }\end{array}$ & $\begin{array}{c}\mu \text { moles } / \mathrm{hr} / \\
0.1 \mathrm{~g} \text { total } \\
\text { wet } \mathrm{wt}\end{array}$ & $\begin{array}{c}\mu \text { moles } / 0.1 \\
\mathrm{~g} \text { total dry } \\
\text { wt }\end{array}$ & $\begin{array}{l}\mathrm{m} \mu \text { moles/ } \\
\mathrm{cm} \text { length }\end{array}$ & $\begin{array}{c}\text { Net water } \\
\text { secretion } \\
(\mathrm{ml} / \mathrm{hr} \mathrm{g} \\
\text { wet wt }\end{array}$ \\
\hline
\end{tabular}

14- to 15-day old

rats

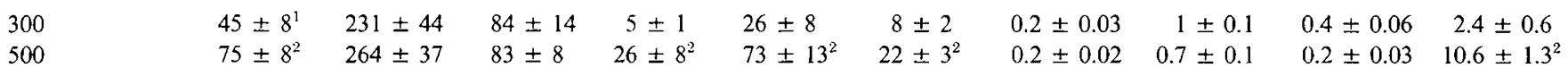

21- to 22-day-old

rats

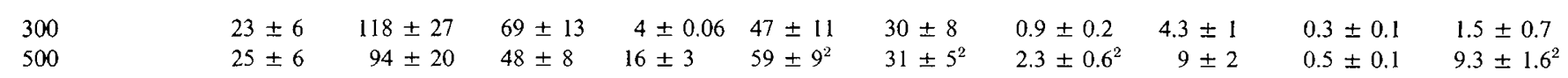

42- to 43-day-old

rats

\begin{tabular}{lllllllllll}
300 & $4 \pm 0.5^{3}$ & $17 \pm 1^{3}$ & $25 \pm 3$ & $7 \pm 1$ & $35 \pm 5$ & $47 \pm 2$ & $0.05 \pm 0.02^{3}$ & $0.1 \pm 0.07^{3}$ & $0.2 \pm 0.01$ & $-0.1^{4} \pm 0.1^{3}$ \\
500 & $8 \pm 2^{2,3}$ & $31 \pm 3^{2,3}$ & $54 \pm 11$ & $7 \pm 1^{3}$ & $31 \pm 3^{3}$ & $42 \pm 3$ & $0.04 \pm 0.01^{3}$ & $0.2 \pm 0.07^{3}$ & $0.3 \pm 0.08$ & $2 \pm 0.5^{2,3}$ \\
\hline \multicolumn{10}{c}{ Distal } \\
\hline
\end{tabular}

14- to 15-day-old

rats

\begin{tabular}{|c|c|c|c|c|c|c|c|c|c|}
\hline 00 & $\begin{array}{l}32 \pm 8 \\
37+4\end{array}$ & $\begin{array}{l}159 \pm 50 \\
117 \pm 18\end{array}$ & $\begin{array}{l}47 \pm 13 \\
42 \pm 5\end{array}$ & $\begin{aligned} 3 & \pm 0.5 \\
12 & +4\end{aligned}$ & $\begin{array}{l}18 \pm 8 \\
43 \pm 11\end{array}$ & $\begin{array}{r}5 \pm 2 \\
+2\end{array}$ & $0.25 \pm 0.07$ & $1.3 \pm 0.5$ & $5.4 \pm 1.8$ \\
\hline
\end{tabular}

21- to 22-day-old

rats

$\begin{array}{lcccccccccc}300 & 23 \pm 3 & 120 \pm 12 & 60 \pm 10 & 3 \pm 0.04 & 18 \pm 3 & 8 \pm 5 & 0.6 \pm 0.1 & 3.3 \pm 0.7 & 0.15 \pm 0.06 & 0.5 \pm 2 \\ 500 & 25 \pm 4 & 96 \pm 14 & 37 \pm 4 & 14 \pm 2 & 58 \pm 7 & 21 \pm 3 & 3.3 \pm 0.4 & 14 \pm 3 & 0.7 \pm 0.2 & 9.4 \pm 1.8\end{array}$

42- to 43-day-old

rats

\begin{tabular}{|c|c|c|c|c|c|c|c|c|c|c|}
\hline $\begin{array}{l}300 \\
500\end{array}$ & $\begin{array}{l}7 \pm 0.6^{3} \\
8 \pm 1^{3}\end{array}$ & $\begin{array}{l}37 \pm 2^{3} \\
31 \pm 5^{3}\end{array}$ & $\begin{array}{l}43 \pm 4 \\
41 \pm 4\end{array}$ & $\begin{array}{l}2 \pm 0.5 \\
4 \pm 1\end{array}$ & $\begin{array}{l}10 \pm 2 \\
19 \pm 7\end{array}$ & $\begin{array}{l}11 \pm 2 \\
19 \pm 4\end{array}$ & $\begin{array}{l}0.04 \pm 0.01 \\
0.06 \pm 0.01\end{array}$ & $\begin{array}{l}0.1 \pm 0.02 \\
0.2 \pm 0.02\end{array}$ & $\begin{array}{l}0.2 \pm 0.02 \\
0.3 \pm 0.03\end{array}$ & $\begin{array}{r}-0.2 \pm 0.1^{4} \\
1.5 \pm 0.6^{3}\end{array}$ \\
\hline \multicolumn{11}{|c|}{ Colon and Cecum } \\
\hline 300 & $5 \pm 0.5$ & $27 \pm 8$ & $11 \pm 4$ & $2 \pm 0.5$ & $12 \pm 2$ & $5 \pm 1$ & $0.3 \pm 0.05$ & $1.7 \pm 0.04$ & $0.6 \pm 0.1$ & $6 \pm 1.4$ \\
\hline 500 & $21 \pm 4^{2}$ & $80 \pm 15^{2}$ & $33 \pm 7$ & $7 \pm 1^{2}$ & $27 \pm 6$ & $12 \pm 4$ & $0.5 \pm 0.07^{2}$ & $2 \pm 0.2$ & $0.8 \pm 0.08$ & $14.6 \pm 3^{2}$ \\
\hline
\end{tabular}

21- to 22-day-old

rats

\begin{tabular}{|c|c|c|c|c|c|c|c|c|c|}
\hline 300 & $11 \pm 1$ & $61 \pm 6$ & $60 \pm 9$ & $3 \pm 0.04$ & $17 \pm 1$ & $17 \pm 2$ & $0.7 \pm 0.2$ & $3.8 \pm 1$ & $1.5 \pm 1$ \\
\hline 500 & $14 \pm 2$ & $55 \pm 7$ & $50 \pm 7$ & $6 \pm 1$ & $22 \pm 3$ & $29 \pm 8$ & $3 \pm 1^{2}$ & $13 \pm 4$ & $1.4 \pm 0.6$ \\
\hline
\end{tabular}

42- to 43-day-old

rats

\begin{tabular}{lllllllllll}
300 & $5 \pm 0.2$ & $18 \pm 2$ & $41 \pm 6$ & $2 \pm 0.7$ & $12 \pm 4$ & $28 \pm 8$ & $0.03 \pm 0.01^{3}$ & $0.1 \pm 0.04^{3}$ & $0.3 \pm 0.1$ & $-0.1 \pm 0.1^{3}$ \\
500 & $7 \pm 1^{3}$ & $30 \pm 6^{3}$ & $78 \pm 1.6$ & $2 \pm 0.2^{3}$ & $9 \pm 1^{3}$ & $24 \pm 3$ & $0.04 \pm 0.01^{3}$ & $0.2 \pm 0.02^{3}$ & $0.5 \pm 0.1$ & $0.8 \pm 0.4^{3}$ \\
\hline
\end{tabular}

${ }^{1}$ Mean \pm S.E.

${ }^{2}$ Mean value in segments perfused with hypertonic solution significantly different than the corresponding mean value in segments perfused with isotonic solution $(P<0.05-0.001)$.

${ }^{3}$ Mean values in 6-wk-old rats significantly different than corresponding mean values in 2 -wk-old rats $(P<0.005)$.

${ }^{4}$ Negative values indicate net absorption from lumen into the body. 
Table 3. Calculated total intestinal losses of calcium, magnesium, and zinc, in $\mu$ moles $/ \mathrm{hr} / 100 \mathrm{~g}$ body weight during perfusion with isotonic and hypertonic solutions in the rats studied.

\begin{tabular}{|c|c|c|c|}
\hline $\begin{array}{l}\text { Osmolality of the perfusion solu- } \\
\text { tion }(\mathrm{mOsm} / \mathrm{kg})\end{array}$ & Calcium & Magnesium & Zinc \\
\hline \multicolumn{4}{|l|}{ 14- to 15-day-old rats } \\
\hline 300 & 10.8 & 1.4 & 0.08 \\
\hline 500 & 12.7 & 4.2 & 0.065 \\
\hline
\end{tabular}

21- to 22-day-old rats

$\begin{array}{rrcc}300 & 11.5 & 3.2 & 0.04 \\ 500 & 9.0 & 5.2 & 0.1\end{array}$

42- to 43-day-old rats

$\begin{array}{llll}300 & 2.5 & 2.1 & 0.014 \\ 500 & 3.8 & 2.3 & 0.02\end{array}$

$(P<0.05)$ in all segments of the weanling rats, but only in the cecum plus colon segments of the suckling rats. In all age groups, the net secretion of zinc from the cecum plus colon segments was either similar to or greater than the net secretion from proximal or distal segments. However, in no instance was statistical significance achieved.

Table 3 presents the potential losses from the entire intestinal tract of these minerals which are expressed as $\mu$ moles $/ \mathrm{hr} / 100 \mathrm{~g}$ body weight of the rats. The total amounts of calcium, magnesium, and zinc that could be lost from the small bowel was calculated from the available data and with the following assumptions: (1) losses of minerals in the unperfused segments of the small intestine were at a rate similar to the average losses determined from the proximal and distal intestinal segments; (2) the total length of the small intestine in the suckling rat is $50 \mathrm{~cm}$, in the weanling, it is 65 $\mathrm{cm}$, and in the adolescent, it is $90 \mathrm{~cm}$. These values were based on previous experience with large numbers of rats. The weights of the unperfused small intestine were calculated from the estimated lengths and the mean weight:length ratios of the corresponding proximal and distal segments. The total amounts of calcium, magnesium, and zinc as $\mu$ moles/hr that could be lost from the entire intestinal tract were determined by summing the measured losses from the proximal and distal small intestine and the cecum plus colon, and the estimated losses from the unperfused segments. These calculated values were then expressed per $100 \mathrm{~g}$ body weight. Thus, during isotonic perfusion the potential losses of calcium and zinc were 3- to 5-fold greater in the suckling and weanling rats compared with the adolescent rats. The potential losses of magnesium were not strikingly different amoung the three age groups. During hypertonic perfusion, the potential losses of calcium and zinc were considerably greater in the suckling and weanling rats compared with the adolescent rats. The potential losses of magnesium became two-fold greater in the suckling and weanling rats compared with the adolescent rats.

\section{DISCUSSION}

Water and electrolyte transport across intestinal epithelia is influenced by the osmolality of the luminal contents. In "leaky" epithelia such as that of the small intestine and the gallbladder, 80 to $90 \%$ of the total conductance occurs as a result of diffusion through a paracellular shunt pathway, the electrophysiologic counterpart of the intercellular junctional complexes $(2,8,10)$. Recent data on postnatal development of sodium transport in newborn and suckling rabbits demonstrated a lack of response in net sodium fluxes to the addition of glucose to short-circuited small intestinal epithelium of suckling rabbits compared with adult rabbits. This failure of response in suckling animals was associated with marked paracellular shunting of sodium as evidenced by greater unidirectional fluxes and greater tissue con- ductance (11). NaK ATPase activity, which is believed to be the biochemical sodium pump, was reduced in suckling rabbits compared with adult rabbits (11). Recently, our studies on the maturation of intestinal calcium transport in the rat have indicated that the bidirectional fluxes of calcium were much greater in the suckling rats than in the adolescent rats. Also, in the suckling rat the relationship among luminal calcium concentration, net calcium absorption and lumen-to-mucosa flux was linear. This suggested that the intestinal transport of calcium in the suckling rat is mainly by a passive diffusive process. This was in contrast to what appeared to be an active saturable process in the adolescent rat (4). Together, these studies suggested that the intestinal epithelia of suckling animals is more permeable than that of older animals.

In response to perfusion of hypertonic solutions through the intestinal lumen, net water and electrolyte movements in suckling rats have been compared with that in adults rats. Rates of net secretion from segments of the small intestine were severalfold greater in suckling rats compared with adult rats (15). In leaky epithelia, the volume of mucosa-to-lumen flux was determined to be a function of the area of the intercellular spaces. Inasmuch as increasing the fluid tonicity within the lumen resulted in the collapse of the intercellular spaces, the volume of flow was related to the osmotic gradient in a nonlinear manner $(12,13)$. In suckling rats, however, the volume of flow was related linearly to the osmotic gradient (15). These data provided further indication that suckling animals possessed a more permeable intestinal epithelium than adult animals.

In light of evidence supporting a greater permeability of the intestines of suckling animals compared with adult animals, it was anticipated that if the intestinal lumen of suckling rats were perfused with solutions devoid of calcium, magnesium, and zinc, such minerals would flow into the lumen in greater quantities than in adolescent rats. We tested the validity of this postulate by comparing rates of net secretion of calcium, magnesium, and zinc from the small intestine and the cecum plus colon of suckling, weanling, and adolescent rats when the lumina were perfused with mineral-free isotonic or hypertonic solutions.

The results of the present study have confirmed this hypothesis. For the first time, it has been demonstrated that the age-related differences in intestinal epithelial permeability affect movement within the lumen not only of sodium and water but also of certain major minerals and trace elements. During perfusion with isotonic mineral-free solutions, calcium and zinc losses in the small intestines were severalfold greater in the suckling rats compared with the adolescent rats. For calcium, these losses were similar to small intestinal losses determined previously in a study by one of the authors (3). In the cecum plus colon, calcium losses were similar in the two age groups; however, zinc losses were significantly greater in the suckling rats compared with the adolescent rats. Magnesium losses were comparable in all age groups in all corresponding segments.

During perfusion with hypertonic solutions, in general, the magnitude of mineral losses was significantly greater in the suckling rats compared with the adolescent rats. This was true not only for calcium and zinc but also for magnesium. The only exception was the comparison of calcium secretions in the distal small intestines which did not achieve statistical significance. Within each age group, during hypertonic perfusions, the secretion of calcium and magnesium was significantly greater in the proximal and cecum plus colon segments of the suckling rats than during isotonic perfusions. For zinc secretion in the suckling, this was true only for the cecum plus colon segments. Within the adolescent group, only calcium secretion in the proximal segments was significantly greater during the hypertonic versus the isotonic perfusions.

The study demonstrated that for calcium and magnesium the maximal losses occurred primarily from the small intestinal segments in the suckling and adolescent rats. In contrast, for zinc the losses from the cecum plus colon segments were at least equal to 
(weanling and adolescent rats) if not greater than (suckling rats) the losses from the small intestinal segments. The potential for net secretion of certain minerals by the colon of infant animals is of particular interest because osmotic diarrhea secondary to carbohydrate malabsorportion subjects the colon to hypertonic fluids from the small osmotically active molecules from carbohydrate degradation.

The magnitude of mineral losses in relation to body weight can be determined by calculating the quantity of mineral losses from the entire intestinal tract. From Table 3, it is evident that suckling rats could potentially lose three- to five-fold more calcium and zinc during either isotonic or hypertonic perfusions compared with adolescent rats. For magnesium during isotonic perfusion, the potential losses were similar in the suckling and adolescent rats; however, during hypertonic perfusion the potential magnesium losses became two-fold greater in the suckling rats compared with the adolescent rats. Another interesting finding relates to the difference in the response of the individual segments to isotonic solution. Calcium secretion was greater in distal segments compared with the proximal segments of the adolescent rats. In contrast, the proximal segments of suckling rats secreted greater amounts of calcium than did the distal segments. The findings of different responses of the intestinal segments in each age group were similar to our previous findings (3) and also similar to observations in adult rats $(16,17)$. These findings suggested that the jejunal segments could conserve calcium more efficiently than the ileal segment in adult rats. This was not true in the suckling rats where calcium loss was higher in the jejunal segments.

Because mineral losses appeared to follow net water movement, net mineral secretion probably occurs through the intercellular pathways by solvent drag. Epithelial cell desquamation during the perfusion procedure cannot account for the observed mineral losses. Microscopic examination of the perfusate disclosed few epithelial cells, and the amount of minerals in the epithelial cells is negligible. Determinations of tissue concentration of minerals in intestinal mucosal scraping of the suckling and adolescent rats were: values, mean \pm S.E. $\mu$ moles $/ g$ wet weight (In suckling rats zinc was $0.39 \pm 0.01$, calcium was $3.0 \pm 0.1$, and magnesium was $9 \pm 0.8$. In adolescent rats, zinc was $0.34 \pm 0.06$, calcium was 2.2 \pm 0.1 , and magnesium was $10 \pm 1.5$ ). These determinations were done in our laboratory.

During periods of osmotic diarrhea, the quantity of minerals lost into the intestinal lumen may predispose infant animals to a depletion of an important proportion of their body stores, especially if oral intake stops abruptly. These findings relate primarily to infant rats; human newborns' intestinal mucosa could be more mature than suckling rats. Infants rarely suffer clinically from hypocalcemia, hypomagnesemia, or hypozincemia, possibly be- cause such losses are compensated for by mobilization of minerals from body stores. However, infant animals or humans who experience repeated episodes of osmotic diarrhea may develop significant subclinical depletion of their body stores of minerals. In the long run, such deficits may have profound effects upon various aspects of growth and development.

\section{REFERENCES AND NOTES}

1. Brown, W. B., Jr., and Hollander, M.: Statistics: A Biomedical Introduction. p. 90 (John Wiley \& Sons, New York, 1977).

2. Frizzell, R. A., and Schultz, S. E.: Ionic Conductances of extracellular shunt pathway in rabbit ileum: influence of shunt of transmural sodium transport and electrical potential differences. J. Gen. Physiol., 59: 318 (1972).

3. Ghishan, F. K., Jenkins, J. T., and Younoszai, M. K.: Intestinal calcium loss in infant rats. Proc. Soc. Exp. Biol. Med., 161: 70 (1979).

4. Ghishan, F. K., and Younoszai, M. K.: In vivo transport of calcium in the small intestine and cecum + colon during maturation. J. Nutr. 110: 1622 (1980).

5. Koldovsky, O.: Development of the Functions of the Small Intestine in Mammals and Man. (S. Karger, Basel, 1969).

6. Miller, D. L., Hamburger, S. A., and Schedl, H. P.: Effects of osmotic gradients on water and solute transport: in vivo studies in rat duodenum and ileum. Am. J. Physiol., 237: E389 (1979).

7. Miller, S. A., and Czajka, D. M.: The influence of dietary osmolarity on survival in the neonatal rat. Biol. Neonate, 11: 197 (1967).

8. Okada, Y., Irimajiri, A., and Inouye, A.: Electrical properties and active solute transport in rat small intestine II. Conductive properties of transepithelial routes. J. Membrane Biol., 31: 221 (1977).

9. Schedl, H. P., and Clifton, J. A.: Small intestinal absorption of steroids. Gastroenterology, 41: 491 (1961).

10. Schultz, S. G., Frizzell, R. A., and Nellans, H. N.: Ion transport by mammalian small intestine. Ann. Rev. Physiol., 31: 51 (1974).

11. Shepherd, R. W., Hamilton, J. R., and Gall, D. G.: The postnatal development of sodium transport in the proximal small intestine of the rabbit. Pediatr. Res., 14: 250 (1980).

12. Smulders, A. P., Tormey, J. McD., and Wright, E. M.: The effect of osmotically induced water flows on the permeability and ultrastructure of the rabbit gallbladder. J. Membrane Biol., 7: 164 (1972).

13. Tomasini, J. T., and Dobbins, W. O., III: Intestinal mucosal morphology during water and electrolyte absorption. A light and electron microscopic study. Dig. Dis., 15: 226 (1970).

14. Younoszai, M. K., and Ghishan, F. K.: In vivo intestinal calcium transport in normal and growth retarded infant rats. J. Nutr., 109: 573 (1979).

15. Younoszai, M. K., Sapario, R. S., and Laughlin, M.: Maturation of jejunum and ileum in rats: water and electrolyte transport during in vivo perfusion of hypertonic solutions. J. Clin. Invest., 62: 271 (1978.)

16. Krawitt, E. L., and Schedl, H. P.: In vivo calcium transport by rat small intestine. Am. J. Physiol., 214: 232 (1968).

17. Younoszai, M. K., and Schedl, H. F.: Intestinal calcium transport: comparison of duodenum and ileum in vivo in the rat. Gastroenterology, 62: 565 (1972).

18. Requests for reprints should be addressed to: Fayez K. Ghishan, M.D., Vanderbilt University Hospital, Department of Pediatric Gastroenterology, Nashville, Tennessee 37232 (USA).

19. This research was supported by B.R.S.G. RR05424-18, Vanderbilt University Medical School and the Thrasher Research Fund.

20. Received for publication June 2, 1980

21. Accepted for publication October 7, 1980. 